\title{
Postsecondary Instructors' Perspectives on Teaching English as a Foreign Language by Means of a Multimodal Digital Literacy Approach
}

\author{
https://doi.org/10.3991/ijet.v15i18.15451 \\ Norah Mansour Almusharraf $(\bowtie)$ \\ Prince Sultan University, Riyadh, Saudi Arabia \\ nmusharrafepsu.edu.sa \\ Joseph F. Engemann \\ State University of New York at Buffalo, Buffalo, USA
}

\begin{abstract}
It can be argued that multimodal digital literacy practices promote the development of literacy skills needed for today's world without being constrained to one mode of learning. Anecdotal evidence suggests that the employment of multimodal practices during instruction within EFL classrooms in the Kingdom of Saudi Arabia (KSA) is minimal and fraught with obstacles to its effective utilization. It is, therefore, important to determine whether this is the case and, if so, to develop strategies that would ameliorate this situation. This study, therefore, sought to identify KSA postsecondary EFL instructors' self-reporting of their use of various types of technology, computer software, and online software; the different teaching/learning and assessment strategies that they employ; the obstacles they face with the use of technology in their classrooms; and their beliefs about the use of multimodal digital literacy practices for teaching and learning. The study, which was based on the premises of social semiotic theory, utilized a mixed-methods design from which survey and focus group interview data were triangulated. The findings demonstrated that while most postsecondary EFL instructors have a strong positive attitude towards multimodal digital literacy practices and make robust use of specific types of technology and software programs, obstacles prevent these practices from being more widely and frequently deployed in the KSA. Suggestions for how to make a transformation to a more pronounced use of multimodal practices happen and the limitations to the study are also presented.
\end{abstract}

Keywords - Information and communication technology, multimodal digital literacy, EFL teaching and learning.

\section{Introduction}

We live in an era where people around the world possess a considerable reliance on information and communication technology. Computers, tablets, and smartphones are essential tools that most people use ubiquitously throughout their personal, 
professional, and / or educational lives. It is, therefore, necessary that such technology, and its concomitant multimodal offerings, serve as a mainstay for teaching and learning. But do they? And more particularly relevant to the aim of this study, to what extent are multimodal digital literacy practices part of the instructional offerings within KSA postsecondary EFL classrooms?

The purpose of this exploratory study was to identify KSA EFL postsecondary instructors' perceptions of the use of multimodal digital literacy practices during instruction. Specifically, this study sought to identify these instructors' self-reporting of their use of various types of technology, computer software, and online software, the different teaching/learning and assessment strategies they employ, the obstacles they face in using technology, and the degree to which they have received professional development on the use of multimodal digital literacy practices.

\section{Review of the Literature}

Multimodal activities can be defined broadly as the ones that focus on the various modalities of learning, such as text, image, gesture, and speech, to encourage meaning-making in the classroom [1]. It is essential to clarify that multimodal activities are not limited to the usage of technology. It is mainly the integration of multiple modes to improve learners' experiences, their understanding of the English input materials, and their engagement in the learning context. Digital literacy is another term that refers to a constituent of media literacy on various digital platforms; it refers to a learner's ability to explore, assess, create, and deliver clear evidence of learning through writing and other forms of communication. It is critical to point out that using multimodal activities with the EFL students is a shared responsibility between the teacher and learner [2]. In other words, through the use of social networking platforms, EFL students can share experiences and produce assignments with a teacher in digital space platforms. Similarly, a teacher can also interact with a learner on particular learning problems and give feedback, hence creating a mutual learning process [3]. For example, the use of new English vocabulary can be taught through social media platforms, and a teacher can request learners to construct sentences or write a story using specific terms.

Mills [4] stated that literacy has historically focused more on written language, and other forms of communication, such as music and visuals, have been regarded as marginal. Chisholm [5] argued that traditional approaches to literacy teaching, which rely mostly on the printed text, are restrictive and insufficient. He stressed the need to integrate new multimodal methods, such as multimedia technologies, as a way of increasing learner engagement. Also, giving personalized multimedia activities (i.e., multimedia that highlight the face and / or voice of the instructor) to EFL students makes them more engaged compared to less personalized activities [6]. Multimodal approaches, as Chisholm [5] claimed, aids student control of knowledge, activates interest in the subject matter, and guides the understanding of many concepts. Other studies [1], [7] have suggested that schools require a wide range of expertise and multiple multimodality resources to increase learner understanding of concepts and 
ideas related to new literacies, which focus on digital literacies, such as social networking sites, text messaging, and online communication. The idea of shifting from the traditional methods of language teaching to more innovative teaching modes has a strong line of research advocates [8], [9] who emphasize the significance of using multimodal activities in English language classrooms for language development.

According to Kress [10], over the past few decades, learners have come to rely on more on-screen text (e.g., platforms like Blackboard or PowerPoint presentations) and less on-page text. This noticeable shift has implications for the development of English language learning [11]. Wiseman et al. [11] stated that it is difficult for adult learners to concentrate without new technologies because such technologies link the classroom to the outside world [12]. The idea that technology establishes connectivity with a real-life experience requires teachers to consider how they link what is planned for instruction to what students are dealing with throughout their working and learning environments. When students are actively involved in the learning process, they will be able to organize content into a helpful schema [4]. In this regard, a shift from monomodal to multimodal learning allows students to learn experientially. Smith [13] pointed out that EFL classroom interaction does not only depend on the availability of technological resources but also entails the usage of multimodal semiotic inputs (e.g., photo essays, e-comics, and podcasts) that create a difference in learning experiences.

It can be argued that the current turn to digital literacy provides multiple opportunities for EFL learners to experience an enhanced learning process through writing and reading in a virtual environment. Bezemer and Kress [14] pointed out that school materials necessitate "a shift from stability, canonicity and vertical power structures to 'horizontal', more open, participatory relations in the production of knowledge" (p. 10). They also affirmed that providing several modes of representations in school curricula develops learners' literacy comprehension. According to several recent studies [6], [7], [15], multimodal activities facilitate this natural learning development. One example can be seen in Guo \& Xu's [16] study where they found that the incorporation of multimodal activity within the college English curriculum can increase learners' motivation and stimulate the teaching environment. Similarly, Pan and Zhang [17] and Sun [18] found that multimodal teaching can create a greater collaboration between teachers and students, especially within the EFL learning environment (i.e., speaking and reading development).

Goss, Castek, and Manderino [19] stated that multimodal activities create a springboard that brings satisfaction to various learning styles and cognitive discrepancies, which enables the learner to achieve learning goals. Goss et al. affirmed that using multimodal teaching brings creativity as well as flexibility between a teacher and a student during English language classroom interaction and improves the learning environment as a result. The authors explained that "Digital devices and the Internet provide access to infinite information resources, including many with digital enhancements such as simulations, animated 3-D models, dynamic representations, and embedded images, audio, and video segments that are linked within texts" (p. 338). These digital tools, according to Goss et al., aid in 
"synthesizing and making sense of information that comes from a wide variety of sources and perspectives" (p. 338). Therefore, the authors affirmed that learners need to be "digitally literate" and know how to use social media effectively to be employable. The application of a multimodal teaching approach could stimulate students' participation in English reading. Goss et al. also found that a great majority of the students in their study thought that the English reading class, within which the instructor applied a multimodal approach, was more stimulating and these students were more willing to participate in classroom activities because of the new teaching method.

For learners, having an opportunity to use multimodal texts gives rise to the development of innovative and critical thinking. For example, allowing learners to produce multimodal compositions, such as video compositions and screencast, enhances their writing and communication skills. Learners can also develop critical social skills, such as leadership, problem solving, and cooperation, by interacting online. The multimodal components provide a higher chance for students to participate with their peers in various ways through written, spoken, and visual texts, thereby raising their level of critical thinking by reflecting, critiquing, and providing constructive comments. Dalton and Smith [1] stated that engaging learners in the lesson involve an application of various communication strategies, and the use of communication strategies enables learners to maintain attentiveness, work on simple cognitive styles, and stimulate effective ways of memory creation.

From a broader perspective, the facilitation of multimodal teaching allows learners to gain essential (practical) language skills that are required to succeed in the career paths after completing college [20]. Through social networking, learning has become more comfortable, and learners can use multimodal texts, such as videos, to gain more competencies and become more competitive in their career paths. Pandya [20] stated that "multimodal composition leads to increases in skill development in traditional writing" (p. 184). When learners apply theory to practice, they can examine the relationship between what they have learned in the classroom (e.g., expressing their opinions in an open Blackboard discussion) and their future professions (e.g., writing an evaluative performance of selected companies). Therefore, engaging learners in multimodal learning is essential for creating an open relationship between the various competencies developed with learning activities.

Multimodal evaluation feedback can serve various purposes for different stakeholders in the education sector, including instructors, learners, and curriculum designers. The adoption of these kinds of evaluations should facilitate the EFL learning process. McVee and Boyd [21] affirmed that using multimodal formative evaluation responds to EFL learners' needs. For example, during the learning process, EFL students can use authentic texts - texts that are based on real context and related tasks - to learn the English language, which connects their learning with real-life dynamic competencies.

Because most undergraduate students were born in the so-called digital age and have developed some technological competence as a matter of course, the use of printed texts alone in EFL classrooms could hinder their language learning experience [7], [8], [15]. In KSA college settings, teachers use a traditional didactic instructional 
mode [22], because it has been argued that some aspects of traditional instruction are still needed and are prominent in countries such as the KSA [23]. For EFL learners in the KSA, the application of these changes in English textbooks through digital technologies should enhance the quality of learning and make it easier to grasp new content [22].

While there has been considerable attention in the literature paid to the use of multimodal approaches with K-12 learners in the U.S., Canada, and Australia [24][29], little research has been done on how these approaches are being used in KSA postsecondary EFL classrooms. Thus, it is essential to clarify that the use of multimodal activities is situated within social literacy practices that aim to connect and engage EFL learners in a more dynamic learning experience [30]. This investigation is necessary for improving the classroom experience, enhancing the level of integration between learners and teachers, and strengthening overall classroom communication in the KSA. Furthermore, there is limited practical literature on teachers' perceptions of using multimodal digital media in EFL contexts.

This research is based on the premise of the multimodal social semiotics theory [31]. In Halliday's [31] view, language is used to make meaningful interactions and connections using a variety of modes. According to Kress [9], multimodality contributes to learning using diverse modes of communication, such as images, graphs, and music, to produce meaning. Kress believed that every mode portrays its own function; for example, the image portrays what can take too long to read and understand, and colour represents a specific theme or a general message. The image, for instance, plays a very integral function in multimodal communication because of its ability to grasp readers' attention [32]. Fisher and Frey [33] perceived multimodality as a wide range of texts that apply two or more modes to convey their meanings.

The following are the research questions that will underpin this study:

1. What types of multimodal digital literacy practices do instructors and their students use in Saudi Arabian postsecondary EFL programs?

2. What are these instructors' perceptions about usefulness and ease of use of multimodal digital literacy practices?

3. What do these instructors perceive as barriers to the implementation of multimodal digital literacy practices?

\section{$3 \quad$ Method}

\subsection{Participants}

Individuals considered eligible for participation in this research were those who taught English at a postsecondary institution in the KSA. The deans of English instruction-related departments within these institutions were contacted by email asking them to forward a request for participation in this research to all faculty within their department. There were 137 respondents who fully completed the survey, but 18 
of these were deemed ineligible for not meeting the a priori criteria, therefore leaving 119 respondents whose survey data were used for quantitative analysis. Demographic information on these participants is included in Table 1.

This research was reviewed and cleared by the Institutional Review Board of Prince Sultan University (PSU IRB-2019-09-0016). Survey participants were informed, within the welcome message, that completion of the survey implied their consent to participate in this research. Focus groups participants, however, were required to read, sign, and forward an informed consent form before participating in the interview. No compensation was offered to any participants who completed the survey, but those who agreed to participate in a focus group interview were offered a certificate of participation in research.

Table 1. Participants' demographic information

\begin{tabular}{|l|c|}
\hline \multicolumn{1}{|c|}{ Age (years) } & n (\%) \\
\hline $19-26$ & $21(17.6 \%)$ \\
\hline $31-40$ & $64(53.8 \%)$ \\
\hline $41+$ & $34(28.5 \%)$ \\
\hline Gender & $n(\%)$ \\
\hline Female & $107(89.9 \%)$ \\
\hline Male & $9(7.6 \%)$ \\
\hline Not reported & $3(2.5 \%)$ \\
\hline Highest academic degree & $n(\%)$ \\
\hline Bachelor's (e.g., BA, BS) & $15(12.6 \%)$ \\
\hline Master's (e.g., MA, MS, MEd) & $76(63.9 \%)$ \\
\hline Doctorate (e.g., PhD, EdD, MD, DDS, DVM) & $27(22.7 \%)$ \\
\hline Not reported & $1(0.8 \%)$ \\
\hline Professional certification (e.g., TOEFL, IELTS, CELTA, DELTA) & $n(\%)$ \\
\hline Yes & $33(27.7 \%)$ \\
\hline No & $86(72.3 \%)$ \\
\hline Length of time teaching English (years) & $n(\%)$ \\
\hline$\leq 5$ & $36(30.2 \%)$ \\
\hline $6-10$ & $42(35.2 \%)$ \\
\hline $11+$ & $40(33.6 \%)$ \\
\hline Not reported & $1(0.8 \%)$ \\
\hline
\end{tabular}

\subsection{Measures}

Survey: The survey used in the current study was developed by the researchers. It was based on information about multimodal digital literacy use in EFL classrooms from the extant literature and from the experience of the first author, who is a practicing EFL postsecondary instructor in the KSA. Initial questions within the survey prompted the respondents to provide demographic information about themselves. The remaining questions required Likert-scale responses about the participants' multimodal digital literacy practices using technology, computer software, and online software; their use of various types of teaching/learning and assessment strategies; the obstacles they face in trying to use these practices; their use of and beliefs about the different modes of communication; and their belief in the value of implementing multimodal digital literacy practices in their instruction. 
The survey was reviewed by four experienced KSA postsecondary EFL instructors with an academic rank of associate professor or higher within the field of applied linguistics, and changes were made to the organization of the survey and the questions within each section of the survey based on their recommendations. LimeSurvey was the online platform within which the survey was created and through which it was distributed. The survey was made available to eligible faculty in November 2019 and was kept open for approximately 2 months, at which time it was ascertained by the researchers that no further responses were likely forthcoming.

Descriptive statistical analyses of the survey were conducted using SPSS, version 26. Responses to each question in the survey are described within the findings as a percentage of the participants who chose a particular Likert scale response category and as a mean and standard deviation. The total number of participants who responded to each question is also indicated. Differences in the total number of respondents among the survey questions exist because some participants failed to respond to one or more questions.

Focus group interviews: Qualitative data were collected through virtual focus group interviews using WhatsApp. Forty-four of the survey participants indicated on the survey that they would be interested in being interviewed; of those, only eight were available to participate on the dates when the focus group interviews were scheduled, three in the first interview, and five in the second. Both interviews were audiotaped and transcribed. These data were then entered into NVivo, version 12 through which content analysis was undertaken to identify codes and develop themes.

\section{$4 \quad$ Findings}

Within this section, the findings from this study are organized according to the topics covered in the survey and the themes generated through the qualitative data content analysis. Whenever direct quotes from the participants are presented within the findings, pseudonyms are used to identify who they are in order to protect their identities.

\subsection{Types of technology use}

Descriptive statistics from an analysis of the survey data pertaining to the participants' self-reported use of various types of technology during instruction are reported in Table 2. From these results, it can be seen that computers and LCD projectors are the technologies used frequently/very frequently by a majority of the participants. An almost equal percentage of participants reported using interactive whiteboards either frequently/very frequently or never/very rarely/rarely. Just over three-quarters of the participants reported employing smartphones occasionally/frequently/very frequently during instruction, while a little less than $50 \%$ and only $20 \%$ of the instructors reported using tablets and digital cameras, respectively, to this same degree of frequency. 
During the interviews, most of the participants indicated that they made extensive use of technology during instruction. As an example of a typical response to a question about technology use, one participant made the following statement:

In our classrooms, we have desktop computers, and we have LCD projectors, and the students have the chance to use their smartphones if there is a need for that. For interactive whiteboards, it is the best thing that we are using here since all the students like to see the moveable things and the colours on the board itself and will give us a chance to create many materials related to the topics or to the course itself. (Maha)

But one participant noted that she would have liked to use technology for instruction within the classroom but was not able to do so. She stated,

I think the university is not applying much technology in the class because there's no PowerPoint, no smartboards in the class. So, it's hard for me to bring all the things with me in the class. (Rana)

A number of participants talked about the types of technology that their students use within the classroom during lectures. One participant declared that

Students also use either their smartphones or computers. Mostly, they prefer to use their smartphones or iPads because it is easier for them to carry around rather than their laptops. (Alaa)

Table 2. Frequency of types of technology use

\begin{tabular}{|l|c|c|c|c|c|}
\hline $\begin{array}{c}\text { Types of } \\
\text { Technology }\end{array}$ & $\begin{array}{c}\text { Never/ } \\
\text { Very Rarely/ } \\
\text { Rarely }^{\mathbf{a}}\end{array}$ & Occasionally & $\begin{array}{c}\text { Frequently/ } \\
\text { Very Frequently }\end{array}$ & N & Mean (SD) \\
\hline $\begin{array}{l}\text { Laptops or } \\
\text { desktop } \\
\text { computers }\end{array}$ & $5 \%$ & $9 \%$ & $86 \%$ & 118 & $5.42(1.07)$ \\
\hline $\begin{array}{l}\text { Digital } \\
\text { cameras }\end{array}$ & $80 \%$ & $12 \%$ & $8 \%$ & 115 & $2.26(1.43)$ \\
\hline $\begin{array}{l}\text { Interactive } \\
\text { white boards }\end{array}$ & $44 \%$ & $15 \%$ & $42 \%$ & 117 & $3.75(1.90)$ \\
\hline $\begin{array}{l}\text { LCD } \\
\text { projectors }\end{array}$ & $6 \%$ & $18 \%$ & $76 \%$ & 117 & $5.21(1.14)$ \\
\hline Smartphones & $23 \%$ & $21 \%$ & $56 \%$ & 118 & $4.50(1.53)$ \\
\hline Tablets & $55 \%$ & $16 \%$ & $29 \%$ & 116 & $3.12(1.90)$ \\
\hline
\end{tabular}

A Data from these response categories were combined.

\subsection{Types of computer software use}

The participants' self-reported use of different types of computer software is displayed in Table 3. As expected, word processing and presentation software are the programs used by the greatest and second greatest percentages of participants, respectively, frequently/very frequently. In contrast, E-reader and reference management software were used never/very rarely/rarely by just over $65 \%$ of the participants. An almost equal number of participants also reported using desktop publishing software either frequently/very frequently or never/very rarely/rarely. 
During the interviews, participants made little reference to any computer software programs that they used during instruction. However, considering the high percentage of survey participants who reported using word processing and presentation software frequently/very frequently, it is unlikely that most of the interview participants did not make extensive use of these programs. The only computer software program that was mentioned during the interviews was PowerPoint. For example, as one participant stated,

I sometimes use both PowerPoints of students and for short stories. (Rana)

Another participant referred to the use of PowerPoint as the computer software program that, for her, was the singularly most used program during instruction. She indicated,

As for me, we don't have a knowledge that would be very formal or knowing a lot about new technologies, just PowerPoint and some additional strategies that we are trying sometimes, such as blended learning. (Nuha)

Table 3. Frequency of types of computer software use

\begin{tabular}{|l|c|c|c|c|c|}
\hline $\begin{array}{c}\text { Types of } \\
\text { Computer } \\
\text { Software }\end{array}$ & $\begin{array}{c}\text { Never/ } \\
\text { Very Rarely/ } \\
\text { Rarely }\end{array}$ & Occasionally & $\begin{array}{c}\text { Frequently/ } \\
\text { Very Frequently }\end{array}$ & N & Mean (SD) \\
\hline $\begin{array}{l}\text { Desktop } \\
\text { publishing }\end{array}$ & $41 \%$ & $16 \%$ & $44 \%$ & 116 & $3.78(1.95)$ \\
\hline E-reader & $67 \%$ & $16 \%$ & $17 \%$ & 116 & $2.63(1.72)$ \\
\hline Presentation & $6 \%$ & $17 \%$ & $77 \%$ & 116 & $5.18(1.04)$ \\
\hline $\begin{array}{l}\text { Reference } \\
\text { management }\end{array}$ & $66 \%$ & $16 \%$ & $18 \%$ & 116 & $2.64(1.71)$ \\
\hline Word processing & $6 \%$ & $10 \%$ & $84 \%$ & 118 & $5.33(1.03)$ \\
\hline
\end{tabular}

A Data from these response categories were combined.

\subsection{Types of online software use}

The frequency of online software use, as reported by the participants within the survey, is described in Table 4. The descriptive statistics displayed in this table show that only four types of online software programs have greater than $50 \%$ of the participants reporting their use frequently/very frequently. These programs, in descending order of a number of participants using them, include online dictionaries, online videos, online collocation dictionaries, and social media programs. By contrast, more than $50 \%$ of the participants reported never/very rarely/rarely with respect to the use of the remaining types of online software listed on the survey.

The interview data demonstrate the various types of online software programs that participants used and how these programs were used during instruction. For example, one participant mentioned her extensive use of a mobile learning system as follows:

For the smartphones, sometimes we are using some games, and we have to show a link to the students, and they have to open the link by using their smartphones, especially when we are using clicker questions, they also have to choose the answers by using their smartphones, then after that, we will collect all of the correct answers and analyze them, and we will put the good answers and the 
answers that should be corrected, and we will discuss that together in the classroom. (Maha)

This same participant also indicated her use of social media programs during instruction, stating that

We also use social media programs, such as WhatsApp. For each class, there is a WhatsApp group, and to this group, we send some extra materials relating to the topic, such as pictures, videos, and some new ideas about the topic. (Maha)

As can be seen from the responses of the survey participants, most made occasional, frequent, or very frequent use of online videos. This finding is supported by the responses made by many of the interview participants. For example, one participant commented as follows:

I use YouTube sometimes to support listening. I particularly find advertisements useful, one because they are quite short but also, they have themes that are pertinent to the themes that are being explored in our Q Skills series books. (Alaa) She also talked about her use of another online video program, saying that

I use TED Talks a lot, mostly in terms of assigning it for homework or if there are themes or topics that complement what we are covering in class. (Alaa)

Another participant noted her use of online videos by stating that

Some podcasts for which we are trying to find authentic materials because authentic materials will help the students to create a connection between real life and their studying life. For example, we go to some of the BBC audios and TV shows. (Maha)

One participant mentioned her use of a type of online program that had not been listed in the survey; that is, an online English language development program. As she mentioned,

We teach $Q$ Skills series books and, so with Oxford, we are able to have online versions of the books as well as printed copies. Students also have access to the online group for $Q$ Skills. $Q$ Skills also has a discussion board and some other additional activities that support the learning that takes place in the classroom. (Alaa)

Finally, one participant made a note of her use of a readability checker. A readability checker is an online program that can identify the reading level, usually measured as a grade level, of any text up to and including entire books. This participant explained that

For the reading, we are using readability scores for every single text. For example, if the students' level is A1, we have to choose some texts related to this level by using some websites and some applications. The website that we have Inspect a Text, we have to put the text, and it will check every single word, the level of the words, and it will give us some synonyms to replace the words, and it will also give us the chance to simplify the language of that text according to the students' level. (Maha). 
Table 4. Frequency of types of online software use

\begin{tabular}{|c|c|c|c|c|c|}
\hline $\begin{array}{c}\text { Types of Online } \\
\text { Software }\end{array}$ & $\begin{array}{c}\text { Never/ } \\
\text { Very Rarely/ } \\
\text { Rarely } \\
\end{array}$ & Occasionally & $\begin{array}{c}\text { Frequently/ } \\
\text { Very Frequently }\end{array}$ & $\mathbf{N}$ & $\begin{array}{l}\text { Mean } \\
\text { (SD) }\end{array}$ \\
\hline $\begin{array}{l}\text { 3D interactive } \\
\text { reference tools }\end{array}$ & $60 \%$ & $21 \%$ & $19 \%$ & 117 & $2.68(1.74)$ \\
\hline $\begin{array}{l}\text { Automated word lists } \\
\text { and frequency count }\end{array}$ & $60 \%$ & $17 \%$ & $23 \%$ & 118 & $2.97(1.76)$ \\
\hline $\begin{array}{l}\text { Automatic text } \\
\text { summarization tools }\end{array}$ & $78 \%$ & $10 \%$ & $12 \%$ & 118 & $2.34(1.53)$ \\
\hline Blogs & $66 \%$ & $22 \%$ & $13 \%$ & 116 & $2.82(1.46)$ \\
\hline Collaborative writing & $42 \%$ & $20 \%$ & $37 \%$ & 118 & $3.55(1.81)$ \\
\hline $\begin{array}{l}\text { Corpus consultation } \\
\text { and analysis }\end{array}$ & $75 \%$ & $13 \%$ & $11 \%$ & 114 & $2.28(1.55)$ \\
\hline Discussion boards & $52 \%$ & $17 \%$ & $31 \%$ & 116 & $3.28(1.78)$ \\
\hline LMOOCs & $70 \%$ & $13 \%$ & $17 \%$ & 117 & $2.49(1.71)$ \\
\hline Lexical databases & $66 \%$ & $14 \%$ & $20 \%$ & 116 & $2.61(1.71)$ \\
\hline $\begin{array}{l}\text { Mobile learning } \\
\text { systems }\end{array}$ & $64 \%$ & $16 \%$ & $19 \%$ & 118 & $2.66(1.76)$ \\
\hline $\begin{array}{l}\text { Online collocation } \\
\text { dictionaries }\end{array}$ & $25 \%$ & $18 \%$ & $57 \%$ & 117 & $4.30(1.70)$ \\
\hline Online dictionaries & $13 \%$ & $19 \%$ & $68 \%$ & 118 & $4.80(1.37)$ \\
\hline $\begin{array}{l}\text { Online interactive } \\
\text { learning modules }\end{array}$ & $64 \%$ & $19 \%$ & $17 \%$ & 116 & $2.64(1.72)$ \\
\hline Online videos & $12 \%$ & $22 \%$ & $66 \%$ & 118 & $4.90(1.35)$ \\
\hline $\begin{array}{l}\text { Open educational } \\
\text { resources }\end{array}$ & $50 \%$ & $14 \%$ & $36 \%$ & 118 & $3.38(1.83)$ \\
\hline Podcasts & $53 \%$ & $21 \%$ & $26 \%$ & 117 & $3.15(1.76)$ \\
\hline Readability checkers & $74 \%$ & $15 \%$ & $11 \%$ & 116 & $2.24(1.59)$ \\
\hline Social media programs & $32 \%$ & $16 \%$ & $52 \%$ & 118 & $4.02(1.81)$ \\
\hline $\begin{array}{l}\text { Spelling and grammar } \\
\text { checkers }\end{array}$ & $33 \%$ & $27 \%$ & $40 \%$ & 118 & $3.93(1.66)$ \\
\hline Spoken dialog systems & $72 \%$ & $12 \%$ & $16 \%$ & 116 & $2.41(1.66)$ \\
\hline Text analyzers & $77 \%$ & $11 \%$ & $12 \%$ & 116 & $2.25(1.59)$ \\
\hline Translation programs & $54 \%$ & $17 \%$ & $29 \%$ & 115 & $3.09(1.82)$ \\
\hline Vocabulary profilers & $79 \%$ & $9 \%$ & $12 \%$ & 115 & $2.16(1.55)$ \\
\hline Webquests & $86 \%$ & $5 \%$ & $9 \%$ & 114 & $1.77(1.34)$ \\
\hline Wikis & $53 \%$ & $17 \%$ & $30 \%$ & 115 & $3.22(1.73)$ \\
\hline
\end{tabular}

A Data from these response categories were combined.

\subsection{Types of teaching/learning strategy use}

An analysis of the survey data pertaining to the participants' self-reported use of various types of teaching/learning strategies during instruction is reported in Table 5. A large majority of the participants reported using collaborative/cooperative learning (83\%) and lecturing (79\%) frequently/very frequently as part of the teaching/learning experience within their classrooms. Approximately two-thirds of the participants reported using blended, inquiry, student-led, and experiential learning approaches for instruction, while the flipped classroom learning approach was split almost evenly between those who use it frequently/very frequently and those who never/very rarely/rarely use it. 
While all of the interview participants admitted to using varying degrees of lecturing during instruction, only one indicated that it was her primary medium of instruction. As she reported,

I have taught some skills and English literature. And the tools I'm using are based on the kind of lecture that I'm giving in the class, traditional way of teaching, that I am explaining to the students and they are listening with me. (Rana)

A number of participants mentioned their use of the flipped classroom learning approach. This approach is a form of blended learning where both online and face-toface learning experiences complement each other. Students prepare for a lecture by reading and learning about a topic through a digital medium and then meet with other students and the instructor to dialogue and further inquire about what they have read and learned. One participant noted that she made regular use of the flipped classroom model with her classes. She stated that

For flipped classroom, I assign any homework, for the students to watch a video lecture, or read any material related to the topic that we have. They have to read that carefully and bring some questions. During the class time, the students will practice what they learned and what they found in their homework and they will also discuss that with the teacher and with their colleagues. (Maha).

Of particular note was an unexpected revelation by one of the interview participants about her perception of the differences between digital and traditional lecturing approaches on her students' interest and achievement in her English language courses. She revealed the following insight:

To be honest, I found some changes between using technology in some classrooms and not using the technology in other classrooms. With students who use the technologies, even their achievements are higher than the ones which used the traditional way, and even their attitude toward the English itself. For example, they like to go to the classes, and their attendance is higher than in traditional classes. (Maha).

Table 5. Frequency of types of teaching/learning strategy use

\begin{tabular}{|l|c|c|c|c|c|}
\hline $\begin{array}{c}\text { Types of } \\
\text { Teaching/Learning } \\
\text { Strategies }\end{array}$ & $\begin{array}{c}\text { Never/ } \\
\text { Very Rarely/ } \\
\text { Rarely }^{\mathbf{a}}\end{array}$ & Occasionally & $\begin{array}{c}\text { Frequently/ } \\
\text { Very } \\
\text { Frequently }\end{array}$ & N & Mean (SD) \\
\hline Blended learning & $21 \%$ & $20 \%$ & $59 \%$ & 116 & $4.41(1.61)$ \\
\hline $\begin{array}{l}\text { Collaborative/coope } \\
\text { rative learning }\end{array}$ & $6 \%$ & $11 \%$ & $83 \%$ & 116 & $5.27(1.15)$ \\
\hline $\begin{array}{l}\text { Experiential } \\
\text { learning }\end{array}$ & $35 \%$ & $28 \%$ & $37 \%$ & 116 & $3.83(1.64)$ \\
\hline $\begin{array}{l}\text { Flipped classroom } \\
\text { learning }\end{array}$ & $41 \%$ & $25 \%$ & $34 \%$ & 116 & $3.54(1.68)$ \\
\hline $\begin{array}{l}\text { Inquiry-based } \\
\text { learning }\end{array}$ & $29 \%$ & $25 \%$ & $46 \%$ & 116 & $4.06(1.58)$ \\
\hline Lecturing & $9 \%$ & $12 \%$ & $79 \%$ & 116 & $5.08(1.08)$ \\
\hline Student-led learning & $29 \%$ & $34 \%$ & $37 \%$ & 116 & $3.90(1.50)$ \\
\hline
\end{tabular}

A Data from these response categories were combined. 


\subsection{Types of assessment strategy use}

Frequency data pertaining to the self-reported use of different types of assessment strategies are detailed in Table 6. Both summative and formative assessment were used frequently/very frequently by $88 \%$ and $72 \%$ of the participants, respectively. Assessment involving students was also reported being used fairly regularly by the participants, with $83 \%$ of them allowing their students to self-assess and $80 \%$ employing peer assessment among the students occasionally/frequently/very frequently. Just over half of the participants never/very rarely/rarely used computerbased assessment approaches, such as automated writing evaluation, computermediated feedback, and digital portfolios. With respect to portfolios, however, more than two-thirds of the participants indicated that assessment involving paper-based portfolios was utilized occasionally/frequently/very frequently.

The interview participants all indicated that they made use of both formative and summative assessment strategies. Many indicated that the formative assessment they offered was coupled with peer assessment. For example, one participant noted that

We have a series of formative and summative assessments, and peer assessments are part of the process that we use. Actually, it is less about peer assessment and more about peer input, where my students get to look at the work and provide peer corrections before I finally look at the work. (Alaa)

Another participant indicated that while she uses peer assessment with her students, the practice is not without its problems. She revealed that

I normally encourage my students to write together and assess each other, but I noticed a thing that they end up giving themselves A+ by the end of the activity. (Tala)

One participant provided a description of the diversified nature of her assessment practices as follows:

I am using so much formative assessment, usually with peer, so they work in a group and they assess each other. It's like a competition between them and because it's the first-year students. And, of course, quizzes and test exams. Interviews with speaking. I meet every student in the class and interview her. I let her talk about herself and family, ambition, and I give her some topics to talk about. (Rana)

Finally, while none of the participants indicated that they made use of digital portfolios, one participant, an English language instructor at a medical college, described how she made use of paper-based portfolios as follows:

About the portfolio, here we ask the students in the college to prepare a portfolio for all of their work during the whole year. For example, the writing assignments and for some assignments relating to creating scenarios and case studies in one portfolio. We assess each of these portfolios each month and at the end of the semester, depending on the course itself. (Maha) 
Table 6. Frequency of types of assessment strategy use

\begin{tabular}{|l|c|c|c|c|c|}
\hline $\begin{array}{c}\text { Types of Assessment } \\
\text { Strategies }\end{array}$ & $\begin{array}{c}\text { Never/ } \\
\text { Very } \\
\text { Rarely/ } \\
\text { Rarely }\end{array}$ & Occasionally & $\begin{array}{c}\text { Frequently/ } \\
\text { Very Frequently }\end{array}$ & N & Mean (SD) \\
\hline $\begin{array}{l}\text { Automated writing } \\
\text { evaluation }\end{array}$ & $53 \%$ & $15 \%$ & $32 \%$ & 115 & $3.26(1.81)$ \\
\hline $\begin{array}{l}\text { Computer-mediated } \\
\text { feedback }\end{array}$ & $48 \%$ & $22 \%$ & $30 \%$ & 115 & $3.23(1.80)$ \\
\hline Digital portfolios & $73 \%$ & $17 \%$ & $10 \%$ & 115 & $2.23(1.57)$ \\
\hline Paper-based portfolios & $31 \%$ & $19 \%$ & $50 \%$ & 116 & $4.00(1.78)$ \\
\hline Peer assessment & $20 \%$ & $25 \%$ & $55 \%$ & 116 & $4.41(1.38)$ \\
\hline Self-assessment & $17 \%$ & $30 \%$ & $53 \%$ & 115 & $4.44(1.29)$ \\
\hline Formative assessment & $16 \%$ & $12 \%$ & $72 \%$ & 116 & $4.73(1.45)$ \\
\hline
\end{tabular}

A Data from these response categories were combined.

\subsection{Obstacles to using multimodal digital literacy practices}

Participants were asked to identify the degree to which certain factors impeded their ability to make effective use of multimodal digital literacy practices during instruction. This information is detailed in Table 7. A descriptive analysis of the survey found that all of the potential obstacles listed on the survey, with the exception of students' resistance to technology and lack of training, existed somewhat or to a great extent as real obstacles to the use of multimodal digital literacy practices within their classrooms. Most problematic, as reported by the participants, are connectivity issues (75\%), hardware issues (71\%), and lack of technical support (70\%).

The interview participants declared a range of obstacles that impeded their ability to use multimodal digital literacy practices. One of the issues identified as most problematic, where it existed, was the unreliability of connectivity to the internet within the classroom.

Table 7. Obstacles to using multimodal digital literacy practices

\begin{tabular}{|l|c|c|c|c|c|}
\hline \multicolumn{1}{|c|}{ Obstacles } & $\begin{array}{c}\text { Not at All/ } \\
\text { Very Little }\end{array}$ & Somewhat & To a Great Extent & N & Mean (SD) \\
\hline Hardware issues & $28 \%$ & $41 \%$ & $31 \%$ & 118 & $2.96(0.91)$ \\
\hline Software issues & $36 \%$ & $39 \%$ & $25 \%$ & 118 & $2.76(0.98)$ \\
\hline Lack of technical support & $31 \%$ & $40 \%$ & $30 \%$ & 118 & $2.87(0.97)$ \\
\hline $\begin{array}{l}\text { Student resistance to } \\
\text { technology }\end{array}$ & $54 \%$ & $33 \%$ & $13 \%$ & 119 & $2.39(0.97)$ \\
\hline $\begin{array}{l}\text { Student technology use skill } \\
\text { level }\end{array}$ & $47 \%$ & $36 \%$ & $17 \%$ & 119 & $2.57(0.92)$ \\
\hline Lack of training for yourself & $51 \%$ & $31 \%$ & $18 \%$ & 119 & $2.39(1.07)$ \\
\hline $\begin{array}{l}\text { Lack of planning and } \\
\text { implementation time }\end{array}$ & $45 \%$ & $31 \%$ & $24 \%$ & 118 & $2.56(1.09)$ \\
\hline Class size & $29 \%$ & $30 \%$ & $41 \%$ & 119 & $3.03(0.99)$ \\
\hline Connectivity issues & $25 \%$ & $31 \%$ & $44 \%$ & 119 & $3.09(0.98)$ \\
\hline $\begin{array}{l}\text { Lack of administrator } \\
\text { support }\end{array}$ & $40 \%$ & $26 \%$ & $34 \%$ & 119 & $2.76(1.10)$ \\
\hline Lack of university vision & $45 \%$ & $28 \%$ & $27 \%$ & 119 & $2.53(1.17)$ \\
\hline
\end{tabular}

A Data from these response categories were combined. 
As one participant claimed:

In class, we have projectors and I use them all the time, but the internet connection is a problem. In some classes, it's weak and the students have problems logging in or downloading something. I did some online quizzes but unfortunately some students couldn't open them in class. That is why I am lecturing in class and most of the technology work is asked to do out of class. (Nora)

Institutional support for the use of technology and training in its use for pedagogical purposes was strong according to some of the participants, but much less for others. As one pointed out, based on her positive experience,

I found great support from my institution. The way of their support is to support us as English teachers by professional development in the use of technologies. We did some internal and external professional development workshops. After each workshop, we have to come to the classroom, and we have to implement the things that we took in the workshops. (Maha)

Another participant felt very similarly about her experience with support from the institution. As she stated,

We have the dean for technological support, and you can go there and enroll in one of the courses there that they use technology and they will help you through it. And of course, it will take approximately three days, like two hours per day for three days. They are very flexible, and they can repeat the courses for you like within a month twice. (Fay)

But a third participant was less than complimentary about the way that institution dealt with the use of technology within the classroom. She opined that within her institution,

We have confusing rules at our university. For instance, the students are not allowed to use their smartphones in the class, and yet we are expected to access the internet or even ask our students to do online work. And how are they supposed to do that if they cannot access their smartphones? So, it's like these kinds of schizophrenic applications of policy with respect to the digital interface as part of the learning process. (Alaa)

This participant went further with her criticism of institutional support by stating that

The institution where I work, well they state that they are actively supporting the increase of digital learning. And they are in many ways. All of our classrooms have podiums and projectors. The problem is the software is so out of date and the podiums don't often work, so it is really difficult to consistently use these technological tools in the classroom. (Alaa)

Finally, the interview participants were universally convinced that most of their students held very favourable views on the use of digital literacy practices to assist their learning both inside and outside of the classroom. For example, one participant stated that

They [the students] do have positive attitudes. I can't say all of them because there are some who do have technical problems and they face problems and they keep asking me to submit their work in paper hard copy, but the majority, they do 
have positive attitudes towards technology. They are interested. Once I introduce something new, I can feel that they are excited. (Nora)

\subsection{Beliefs about multimodal digital literacy practices}

Within the survey, participants were asked to indicate the strength of their belief about the importance (1=unimportant, 2=of little importance, 3=moderately important, 4=important, 5=very important) of using the different modes of communication within their instruction. Ninety-six percent of the respondents reported the use of auditory and written modes of communication as important or very important, while $95 \%$ and $92 \%$ reported believing that the use of visual and kinesthetic modes, respectively, was either important or very important. In addition, regarding the participants' belief in the importance of each mode for instruction and based on a 5-point Likert scale, a mean and standard deviation of $4.70(0.59)$ for visual, $4.76(0.55)$ for auditory, $4.72(0.60)$ for written, and $4.60(0.66)$ for kinesthetic modes of communication were found.

Participants were also asked about the frequency ( $1=$ never, $2=$ very rarely, $3=$ rarely, $4=$ occasionally, $5=$ frequently, $6=$ very frequently) they believed they used each of the four modes of communication during instruction. Analysis of the data showed that the visual mode was reported as being used frequently or very frequently by $83 \%$ of the respondents, while $90 \%, 87 \%$, and $81 \%$ reported using the auditory, written, and kinesthetic modes, respectively, frequently or very frequently. Analysis also showed that $13 \%, 8 \%, 11 \%$, and $13 \%$ of the respondents reported occasionally as the frequency with which they used the visual, auditory, written, and kinesthetic modes, respectively, in their instruction. Based on a 6-point Likert scale, a mean and standard deviation of $5.36(0.94)$ for visual, $5.47(0.80)$ for auditory, $5.40(0.75)$ for written, and 5.27 (1.03) for kinesthetic modes of communication were reported for the frequency that each mode was used during instruction.

An analysis of the data regarding the participants' belief about the importance of using multimodal digital literacy practices during instruction showed that $66 \%$ of the participants believed such use to be very important or extremely important, $11 \%$ as moderately important, and $17 \%$ as not important, negligibly important, or slightly important, while $6 \%$ reported being neutral and two participants failed to answer this question.

\section{Discussion}

This section provides a review of the findings from the qualitative and quantitative analyses and contributions made regarding EFL instructors' perceptions of utilizing multimodal digital literacy approaches. The first finding reveals that an overwhelming majority of the instructors believed in the significance of using all four modes of communication during the application of multimodal digital literacy practices. Over three-quarters of the instructors also agreed that the use of multimodal digital literacy practices in 21 st-century classrooms is essential. The acknowledgment of the value of 
multimodality is consistent with previous studies [24], [34]-[37], where it was found that appropriate employment of multimodal digital literacy methodologies and resources serves as an optimal intersemiotic complementarity in teaching and learning.

Another key finding of this study is that most instructors are regularly employing multimodal digital literacy practices in their EFL classrooms. Multiple usages of technology were reported by a high percentage of the EFL instructors, but the type of technology employed was, primarily, computers and LCD projectors in concert with the use of smartphones by the students. Interactive whiteboards were also used by a majority of the instructors, but to a lesser degree than computers and LCD projectors. These findings are directly in line with the previous findings of other researchers [38], [39] that EFL instructors are indeed employing multimodal approaches within their practices, and they are utilizing social media platforms heavily for several purposes, including reviewing materials and as an assessment process. However, a difference between these reviewed studies could be attributed to EFL instructors' beliefs that some of the integrated multimodal tools they are using or might use add an extra burden to both themselves and their students, most notably with respect to workload and understanding of technical knowledge. Thus, a recommendation from this current research is to stress the significance of the instructors to be digitally literate so that they can critically assess any multimodal tools and platforms for productive learning practice.

This study also revealed that word processing and presentation software were used very regularly by a great majority of the EFL instructors and, to a lesser extent, desktop publishing software. However, a small minority made use of other forms of computer software programs, such as E-reader and reference management software. Instructors made extensive use of online software programs, but these were mostly limited to the use of online dictionaries, online collocation dictionaries, online videos, and social media programs. This result ties in well with those from previous studies [40], [41], wherein there still exists a gap between the newly emerging technological tools and the proper implications of technological pedagogy in the EFL teaching context. The usage of necessary programming tools is acceptable, but there is a need for different multimodality applications within the EFL context. Moreover, EFL instructors' use of technology in teaching differs in terms of personal preferences and technical skills, which might be viewed by EFL learners as constraints to the learning process. Teng [41] presented a view that several influences are impacting EFL teachers' incorporation of technology into their teaching, including EFL teachers' inadequate knowledge of technology, absence of updated resources and materials for schools and teachers, and lack of specific support for EFL teachers' technical assistance.

The results of instructors' reported employment of multimodal digital literacy practices showed that while lecturing was the preeminent teaching strategy used by the EFL instructors, it was typically complemented by multimodal practices and opportunities for students to learn and work collaboratively. A majority of instructors also used blended and flipped classroom learning to a lesser but still significant degree of frequency. Morell [42] stated that "multimodal competence plays a crucial role in 
effective interactive lecturing, especially when the language of communication is other than one's own" (p. 71). The current study draws a similar conclusion as Morell, which is that effective instruction is mainly related to EFL instructors' multimodal competence, where they comprehend how to combine the potential of different modes for meaning making.

Another interesting finding was that as part of the instructors' reported use of multimodal digital literacy practices was the employment of multiple modes of assessment, including formative assessment, summative assessment, peer assessment, and self-assessment. Unexpectedly, however, there was a very minimal use reported by the EFL instructors of computer-based assessment approaches, such as automated writing evaluation and computer-mediated programs, and while some used portfolios for their assessment of students, these portfolios were mostly paper-based rather than digital. This finding is inconsistent with prior research [40], where it was suggested that assessment in the EFL context should incorporate multimodality. The findings of the study [43] study revealed that multimodal assessment in the EFL instruction (e.g., comments in response to peers on Facebook and their blogs) allows room for the learners to be creative and self-regulated.

The findings of this study also indicated that the primary obstacles to EFL instructors' implementation of multimodal digital literacy practices are internet connectivity, class size, and lack of technical support. Instructors also reported a substantial degree of acceptance of and aptitude for the use of technology by their students. Other potential obstacles, such as software and hardware issues and lack of institutional support, limited the ability of a small majority of the instructors to provide consistent use of technological applications within the classroom. These findings are consistent with other research [44], who showed that there is a vital need to foster higher levels of inclusion of technology support to empower pedagogical practices related to EFL instructors and learners inside and outside the classroom context.

\section{Conclusion}

The results of this study shed light on the contemporary digital literacy practices of EFL instructors in the KSA, which serves as an aid for educational policymakers and teacher trainers in teacher education for the 21 st century. Implications and further research are discussed to equip postsecondary instructors with the competences to integrate content, instruction, and technology and to comprehend the complex interdependence of contextually bound influences that impact their classroom promptness in teaching multimodal literacies.

There are a number of limitations to this research. First and foremost is the concern about the validity of the responses provided by the respondents to the survey questions. As has been noted [45], self-report data, such as that which was provided through the survey and focus group interviews within this study, may be subject to social desirability bias. Second, while there was a robust sample of respondents to the survey, there were fewer interview participants than were hoped for. It would have 
been desirable to interview survey participants who were outliers concerning their responses to some of the survey questions; for example, one of the $8 \%$ of participants who made frequent or very frequent use of digital cameras within their instruction. Finally, there is no way to know whether the sample participants who responded to the survey are representative of the population of postsecondary EFL instructors across the KSA.

It can be concluded, at least with respect to the participants within this study, that the use of technology and multimodal digital literacy practices are, to varying degrees, an almost universal staple of postsecondary EFL instruction in the KSA. With more opportunities for training in the pedagogical use of technology and an improvement in the quality of technological infrastructure in colleges and universities, multimodal digital literacy practices should become the mainstay of EFL instruction across the country.

\section{$7 \quad$ Acknowledgement}

The authors thank Prince Sultan University for funding this research project under grant number IBRP-CH-2020-1-1 and in affiliation with the Applied Linguistics Research Lab.

\section{$8 \quad$ References}

[1] B. Dalton and B. E. Smith, "Teachers as designers: Multimodal immersion and strategic reading on the internet," Research in the Schools, vol. 19, no. 1, pp. 12-25, 2012.

[2] D. Bruce, "Writing with visual images: Examining the video composition process of high school students," Research in the Teaching of English, vol. 43, no. 4, pp. 426-450, 2009.

[3] P. A. Towndrow, M. E. Nelson, and W. F. Ysuf, "Squaring literacy assessment with multimodal design: An analytic case for semiotic awareness," Journal of Literacy Research, vol. 45, no. 4, pp. 327-355, 2013. https://doi.org/10.1177/1086296X13504155

[4] K. A. Mills, Literacy Theories for the Digital Age: Social, Critical, Multimodal, Spatial, Material and Sensory Lenses. Bristol, UK: Multilingual Matters, 2015. https://doi.org/10.2 $1832 / 9781783094639$

[5] J. S. Chisholm, "A profile of three high-school students' talk about literature during multimodal instructional activities and whole-class text-based discussions," in 60th Yearbook of the Literacy Research Association, P. J. Dunston, L. B. Gambrell, S. K. Fullerton, V. R. Gillis, K. Headley, and P. M. Stecker, Eds. Oak Creek, WI: Literacy Research Association, 2011, pp. 245-262.

[6] M. Cinque and M. Bortoluzzi, "Navigating complex challenges: Digital competence and personal knowledge management in university education to foster skills for lifelong learning," International Journal of Technology Enhanced Learning, vol. 5, no. 3-4, pp. 284-298, 2013. https://doi:10.1504/IJTEL.2013.059496

[7] M. Kalantzis, B. Cope, and A. Cloonan, "A multiliteracies perspective on the new literacies," in New Literacies: Multiple Perspectives on Research and Practice, E. A. Baker, Ed. New York, NY: The Guilford Press, 2010, pp. 61-78.

[8] J. Choi and Y. Yi, "Teachers' integration of multimodality into classroom practices for English language learners," TESOL Journal, vol. 7, no. 2, pp. 304-327, 2016. https://doi: $\underline{10.1002 / \text { tesj.204 }}$ 
[9] B. Cope and M. Kalantzis, ""Multiliteracies": New literacies, new learning," in Framing Languages and Literacies: Socially Situated Views and Perspectives, M. Hawkins, Ed. New York, NY: Routledge, 2013, pp. 105-135. https://doi.org/10.4324/9780203070895

[10] G. Kress, Multimodality: A Social Semiotic Approach to Contemporary Communication. New York, NY: Routledge, 2010.

[11] A. M. Wiseman, M. Mäkinen, and R. Kupiainen, "Literacy through photography: Multimodal and visual literacy in a third-grade classroom," Early Childhood Education Journal, vol. 44, no. 5, pp. 537-544, 2016. https://doi.org/10.1007/s10643-015-0739-9

[12] A. A. Wilson, E. Smith, and D. L. Householder, "Using disciplinary literacies to enhance adolescents' engineering design activity," Journal of Adolescent and Adult Literacy, vol. 57, no. 8, pp. 676-686, 2014. https://doi.org/10.1002/jaal.302

[13] B. E. Smith, "Composing across modes: A comparative analysis of adolescents' multimodal composing processes," Learning, Media and Technology, vol. 42, no. 3, pp. 259-278, 2017. https://doi.org/10.1080/17439884.2016.1182924

[14] J. Bezemer and G. Kress, "Visualizing English: A social semiotic history of a school subject," Visual Communication, vol. 8, no. 3, pp. 247-262, 2009. https://doi.org/10.1177/ 1470357209106467

[15] P. Wolfe, "Transmediation as a tool for English language learners to access academic discourse," Yearbook of the National Society for the Study of Education, vol. 109, no. 2, pp. 438-452, 2010.

[16] Z. Guo and L. Xu, "Study on the integration mode of computer network technology and college English curriculum," International Journal of Emerging Technologies in Learning, vol. 11, no. 8, pp. 40-46, 2016. https://doi.org/10.3991/ijet.v11i08.6046

[17] X. Pan and Z. Zhang, "An empirical study of application of multimodal approach to teaching reading in EFL in senior high school," International Journal of Emerging Technologies in Learning, vol. 15, no. 2, pp. 98-111, 2020. https://doi.org/10.3991/ijet.v15 i02.11267

[18] M. Sun, “Application of multimodal learning in online English teaching," International Journal of Emerging Technologies in Learning, vol. 10, no. 4, 2015. http://dx.doi.org/10.3991/ijet.v10i4.4697

[19] M. Goss, J. Castek, and M. Manderino, "Disciplinary and digital literacies: Three synergies," Journal of Adolescent and Adult Literacy, vol. 60, no. 3, pp. 335-340, 2016. https://doi.org/10.1002/jaal.598

[20] J. J. Pandya, "Unpacking Pandora's box: Issues in the assessment of English learners' literacy skill development in multimodal classrooms," Journal of Adolescent \& Adult Literacy, vol. 56, no. 3, pp. 181-185, 2012. https://doi.org/10.1002/jaal.00124

[21] M. B. McVee and F. B. Boyd, Exploring Diversity through Multimodality, Narrative, and Dialogue: A Framework for Teacher Reflection. New York, NY: Routledge, 2016. https:// doi.org/10.4324/9781315700311

[22] A. A. Al-Qahtani, "Do Saudi EFL teachers promote creativity in their classrooms?" English Language Teaching, vol. 9, no. 4, p. 11, 2016. https://doi.org/10.5539/elt.v9n4p11

[23] K. Al-Seghayer, "The four most common constraints affecting English teaching in Saudi Arabia," International Journal of English Linguistics, vol. 4, no. 5, pp. 17-26, 2014. https ://doi.org/10.5539/ijel.v4n5p17

[24] L. Ajayi, "A multiliteracies pedagogy: Exploring semiotic possibilities of a Disney video in a third-grade diverse classroom," Urban Review, vol. 43, pp. 396-413, 2011. https://doi. org/10.1007/s11256-010-0151-0

[25] W. M. Cumming-Potvin and K. Sanford, "Countering a 'back-to-basics' approach to teacher education: Multiliteracies and on-line discussions in a community of practice," Language and Literacy, vol. 17, no. 1, pp. 21-42, 2015. https://doi.org/10.20360/g29w20 
[26] F. Giampapa, "Multiliteracies, pedagogy and identities: Teacher and student voices from a Toronto elementary school," Canadian Journal of Education, vol. 33, no. 2, pp. 407-431, 2010.

[27] E. Hepple, M. Sockhill, A. Tan, and J. Alford, "Multiliteracies pedagogy: Creating claymations with adolescent, post-beginner English language learners," Journal of Adolescent \& Adult Literacy, vol. 58, no. 3, pp. 219-229, 2014. https://doi.org/10.1002/ja al.339

[28] B. Y. Ntelioglou, “'But why do I have to take this class?' The mandatory drama-ESL class and multiliteracies pedagogy," Research in Drama Education: The Journal of Applied Theatre and Performance, vol. 16, no. 4, pp. 595-615, 2011. https://doi.org/10.1080/13569 783.2011.617108

[29] D. Ryu, "Non-native English speakers' multiliteracy learning in beyond-game culture: A sociocultural study," Journal of Online Learning and Teaching, vol. 7, no. 2, pp. 231-243, 2011.

[30] F. Serafini, "Multimodal literacy: From theories to practices," Language Arts, vol. 92(, no. 6, pp. 412-423, 2015.

[31] [31] M. A. K. Halliday, Language as Social Semiotic: The Social Interpretation of Language and Meaning. Baltimore, MD: University Park Press, 1978.

[32] J. P. Gee, "A personal retrospective on the new London group and its formation," in Remixing Multiliteracies: Theory and Practice from New London to New Times, F. Serafini and E. Gee, Eds. New York, NY: Teachers College Press, 2017, pp. 19-30.

[33] D. Fisher and N. Frey, "Student and teacher perspectives on the usefulness of content literacy strategies," Literacy Research and Instruction, vol. 47, no. 4, pp. 246-263, 2008. https://doi.org/10.1080/19388070802300330

[34] X. Bao, "Application of multimodality to teaching reading," English Language and Literature Studies, vol. 7, no. 3, pp. 78-84, 2017. https://doi.org/10.5539/ells.v7n3p78

[35] S. T. A. Hung, "Creating digital stories," Journal of Educational Technology \& Society, vol. 22, no. 2, pp. 26-37, 2019. https://doi:10.2307/26819615

[36] L. Jiang, "The affordances of digital multimodal composing for EFL learning," ELT Journal, vol. 71, no. 4, pp. 413-422, 2017. https://doi.org/10.1093/elt/ccw098

[37] L. Yearta, "Integrating social studies and English language arts: Digital stories and the Revolutionary War," The Reading Teacher, vol. 73, no. 2, pp. 215-218, 2019. https://doi.org/10.1002/trtr.1806

[38] D. Baser, T. J. Kopcha, and M. Y. Ozden, "Developing a technological pedagogical content knowledge (TPACK) assessment for preservice teachers learning to teach English as a foreign language," Computer Assisted Language Learning, vol. 29, no. 4, pp. 749764, 2016. https://doi.org/10.1080/09588221.2015.1047456

[39] L. Tan, C. S. Chai, F. Deng, C. P. Zheng, and N. A. Drajati, "Examining pre-service teachers' knowledge of teaching multimodal literacies: A validation of a TPACK survey," Educational Media International, vol. 56, no. 4, pp. 285-299, 2019. https://doi.org/10.10 $\underline{80 / 09523987.2019 .1681110}$

[40] L. Hsu, "Examining EFL teachers' technological pedagogical content knowledge and the adoption of mobile-assisted language learning: A partial least square approach," Computer Assisted Language Learning, vol. 29, no. 8, pp. 1287-1297, 2016. https://doi.org/10.1080/ 09588221.2016.1278024

[41] Y. Teng, "EFL teachers' knowledge of technology in China: Issues and challenges," in Preparing Foreign Language Teachers for Next-Generation Education, C. H. Lin, D. Zhang, and B. Zheng, Eds. Hershey, PA: IGI Global, 2017, pp. 23-37. https://doi.org/10.4 018/978-1-5225-0483-2.ch002

[42] T. Morell, "Multimodal competence and effective interactive lecturing," System, vol. 77, pp. 70-79, 2018. https://doi.org/10.1016/j.system.2017.12.006 
[43] J. A. Rincón and A. Clavijo Olarte, "Fostering EFL learners' literacies through local inquiry in a multimodal experience," Colombian Applied Linguistics Journal, vol. 18, no. 2, pp. 67-82, 2016. https://doi.org/10.14483/calj.v18n2.10610

[44] H. Motschenbacher, "Non-nativeness as a dimension of inclusion: A multimodal representational analysis of EFL textbooks," International Journal of Applied Linguistics, vol. 29, no. 3, pp. 285-307, 2019. https://doi.org/10.1111/ijal.12237

[45] A. Furnham, "Response bias, social desirability and dissimulation," Personality and Individual Differences, vol. 7, no. 3, pp. 385-400, 1986. https://doi.org/10.1016/0191-8869 (86)90014-0

\section{Authors}

Norah M. Almusharraf is an assistant professor in the Department of Linguistics, Prince Sultan University, Riyadh, Saudi Arabia. Her professional and research interests focus on English as a foreign language (EFL) learning pedagogics, inquirybased teaching and learning, cultural magnitudes of foreign/second language teaching and learning classroom, multimodal assessment and teaching strategies, technology implantation in the EFL English classrooms.

Joseph F. Engemann is an adjunct professor in the Graduate School of Education, State University of New York at Buffalo, Buffalo, U.S.A. His research interests include technology education, STEM education, assessment and evaluation, and mentoring and professional development.

Article submitted 2020-05-06. Resubmitted 2020-06-14. Final acceptance 2020-06-16. Final version published as submitted by the authors. 